\title{
Brand perception across cultures: A comparative study of Skoda's brand characteristics in Poland and the United Kingdom
}

\author{
Justin Beneke \\ Konrad Rozum \\ Winchester Business School \\ University of Winchester, U.K.
}

\begin{abstract}
Keywords
Brand Image, Price, Perceived Quality, Perceived Value; Trust, Purchase Intention, Advertising; Country of Origin
\end{abstract}

\begin{abstract}
This comparative study between the UK and Poland set out to ascertain the key differences in the Skoda motor car brand across a range of brand characteristics, including brand image, price, perceived quality, trust, perceived value, purchase intentions, advertising and the country of origin effect. An online survey was used to collect data across both countries. A sample of 113 respondents was generated, with 58 respondents from the United Kingdom and 55 from Poland. The study found that, in general, the brand image of Skoda in both Poland and the UK was positive. However, it was statistically more positive in Poland. Most brand characteristics were found to be favourable to Skoda, although no further statistical differences were found between the country scores. Although no difference in the country of origin effect was detected statistically, the empirical evidence would suggest some affinity between Poland and Czech Republic, Skoda's home, due to geographic and historical ties between the countries. Polish respondents were more knowledgeable about Skoda's roots, which may account for its higher level of popularity in sales terms within that country. Whilst Skoda's advertising was generally well received, there may be opportunity to embrace a change in tone (e.g. more humorous content) to make the brand more visible and appealing going forward.
\end{abstract}

Corresponding author: Justin Beneke

Email addresses for corresponding author: Justin.Beneke@winchester.ac.uk

First submission received: 13th June 2017

Revised submission received: 3 rd August 2017

Accepted: 1st September 2017

\section{Introduction}

The objective of this study is to examine the brand characteristics of Skoda consumers in the United Kingdom (UK) and in Poland. Skoda generates considerable sales in Poland, whereas the sales figures in the UK are markedly lower. The authors wish to understand, from a marketing perspective, why this may be the case. Brand image, price, perceived quality, trust, perceived value, purchase intentions, advertising and the country of origin effect are all be assessed as potential differentiators between the Polish and British markets for Skoda.

Skoda's history dates back to 1895 when Skoda Automobile was established by its creators, Laurin and Klement. It first specialised in bicycles, then progressed to motorcycles and eventually to cars. The company's headquarters are based in Mlada Boleslav within the Czech Republic (Skoda UK [online]). In 1925, the company was purchased by Skoda Works and taken under state ownership. After 1991, Skoda was steadily privatised and, since 2000, has been a Volkswagen Group subsidiary (English, 2011).

Initially, Skoda was associated with cheap, poor performing cars. However, in recent years, that has changed, and Skoda has become increasingly popular. One of the reasons is value for money. Skoda is well built, yet still maintains a modest price tag. Furthermore, Volkswagen gives Skoda freedom in developing interesting and practical cars that people like (Knapman, 2013). Currently, in Poland and in the UK, Skoda offers seven models: Yeti, Citigo, Rapid, Rapid Spaceback, Octavia, Fabia and Superb. In the UK, the price for new cars ranges from $£ 8000$ for Citigo and $£ 10000$ for Fabia to over $£ 35000$ for the latest, best equipped Skoda Superb (which [online]). In Poland, the price ranges from PLN36 000 for Citigo and PLN40 000 for Fabia to PLN146 000 for Skoda Superb (Skoda PL [online]). Since acquisition by 
the Volkswagen Group, Skoda has placed an emphasis on continually improving its cars. The latest, Skoda Superb, is an attempt to penetrate the more luxurious car market.

This study is thought to be of value in academic, industry and societal contexts. Its bi-national focus allowed the researchers to explore brand characteristics across two different cultural settings in Europe. As such, it was possible to unearth findings that may not be evident in a single-country study. The findings emanating from this research may help the Skoda brand to strengthen its position by determining its relative strengths and weaknesses, with the benefit of cultural interpretation. Finally, there is also potential value to society at large. The study examines Poland and the UK, two European countries with different histories and different economic prowess. The findings may be of value in defining what people in these difficult countries cherish in high value products, such as motor cars.

\section{Literature Review}

Brand equity is a crucial subject in the field of marketing. It has been conceptualised by various scholars, including Aaker (1991), Kapferer (2012) and Keller (2013). This literature review discusses various brand characteristics that are recognised as inputs into developing brand equity, namely: brand image, price, perceived quality, trust, perceived value, purchase intentions, advertising, as well as the country of origin effect.

\section{Brand Image}

Brand image, as defined by Goldberg et al (1990), refers to reasoned or emotional perceptions that consumers attach to specific brands. Brand image is a factor affecting consumers' subjective perceptions and consequent behaviours, and an indication when consumers are evaluating a product prior to purchase (Ryu et al, 2008). Keller (1993) defined brand image as perceptions about a brand reflected by the brand associations stored in consumer memory. A brand association has a level of strength and therefore the link to a brand will be stronger when the link is based on consumers' experience or exposure to marketing communications (Aaker, 1991). Brand associations are grouped into three categories including attributes, benefits and attitudes. Those associations vary based on their strength and uniqueness (Keller, 1993). As noted by Aghekyan-Simonian et al (2012), the more favourable the brand image, the more positive the attribute toward the branded product and its attributes. Additionally, brand image helps a consumer in identifying his/her needs and wants regarding the brand, and distinguishes the brand from its rivals (Anwar et al, 2011).

As discusses by Law \& Lamb (2000), the perceived quality of products/services is crucial to the theory that strong brands add value to consumer purchase evaluations. Positive brand image indicates a brand's favourable image, as well as reflecting a higher level of brand strength than that of competing brands (Kim \& Kim, 2005). When brands possess a favourable brand image, they create a matching level of perceived quality, which subsequently leads to improved sales.

In order to examine the difference in brand image across Poland and the UK, the following hypothesis pair is proposed:

H10: There is no significant difference in Skoda's brand image between Poland and the UK.

H1a: There is a significant difference in Skoda's brand image between Poland and the UK.

\section{Price}

From the consumer's point of view, price represents the amount of money that needs to be forfeited to obtain a given product or service (Zeithaml, 1988; Lichsteiner et al, 1993). A number of consumers utilise price as a cue to reflect quality. Consumers do not always remember actual prices of products, instead they encode prices in ways that are meaningful to them (Zeithaml, 1988). For instance, in online shopping, consumers are likely to compare objective prices that are offered by a current retailer with reference prices that are offered by other retailers and then form their perceptions of price (Kim et al, 2012). The objective price is the total price that consumers need to pay to acquire a product or service, whereas reference price is the price consumers expect to pay to purchase a product or service. As noted by Yoon et al (2014), price as a heuristic cue is more readily noticeable. Consumers learn to distinguish between cues that are diagnostic and those that are not, and price appears to be a straightforward diagnostic cue. In a competitive hotel industry environment, low or reasonable prices help hotels achieve a sustainable advantage within their product markets (Bojanic, 1996). Instead of a single price, consumers 
are usually offered a range of prices that are acceptable for an intended purchase. Similarly, Skoda offers its models at various price points in order to allow consumers to choose the price they are most willing to pay for a certain specification. Price plays a crucial role in consumers' choice of brands. As noted by Keller (1993), many consumers arrange their product category knowledge based on the price bands of different products or services.

In order to examine the difference in price perceptions across Poland and the UK, the following hypothesis pair is proposed:

H20: There is no significant difference in Skoda's price perceptions between Poland and the UK. $\mathrm{H}_{2}$ : There is a significant difference in Skoda's price perceptions between Poland and the UK.

\section{Perceived Quality}

Perceived quality has been defined as the consumer's judgment about a product's overall excellence or superiority. Perceived quality varies from objective quality. The former one refers to a global assessment categorised by a high abstraction level in a specific consumption situation (Zeithaml, 1988), whereas objective quality denotes the actual technical excellence of the product or service that may be measured and verified (Jacoby \& Olson, 1995).

Perceived product quality is considered as a moderator between extrinsic cues and perceived customer value, while it has been argued that price is one of the most crucial extrinsic cues of product quality (Rao \& Monroe, 1999). There are, however, contradicting discoveries on the influence of perceived quality on purchase intentions. Some studies have found perceived quality to have a positive direct effect on purchase intentions (Parasuraman et al, 2006), while others have informed of only indirect effect via satisfaction (Cronin \& Taylor, 2002). Rust \& Oliver (2004) suggested two differences between perceived quality and satisfaction. Perceived quality is considered to be a more specific construct based on product or service features, while satisfaction may result from any dimension, such as loyalty or expectations. Moreover, companies are likely to be able to influence perceived quality. Therefore, Llusar et al (2001) stated that perceived quality is understood as a cause of satisfaction and thus precedes satisfaction.

Perceived quality, in the car industry, is used as a merging word for product quality related to appearance, such as finish, material execution, appearance of paint or details execution. Perceived quality may be an equivalent to craftsmanship (Wang \& Holden, 2000), cosmetic quality (Juster et al, 2001) or design quality (Sodeberg et al, 2006).

In order to examine the difference in quality perceptions across Poland and the UK, the following hypothesis pair is proposed:

$H 3_{0}$ : There is no significant difference in Skoda's perceived quality between Poland and the UK.

$H 3_{a}$ : There is a significant difference in Skoda's perceived quality between Poland and the UK.

\section{Trust}

In marketing terms, as noted by Singh \& Sirdeskmukh (2000), trust has been defined as a psychological state encompassing intention to accept vulnerability based on positive expectations, or a willingness to depend on exchange partners (Ganesan, 1994). Trust refers to a positive belief about the reliability of a person or an object, especially when uncertainty and risk exist. Moreover, McKnight et al (2002) differentiated trust beliefs and trust intentions. Trust beliefs refer to consumers' perceptions of a brand's attributes, which for Skoda could be car dependability or confidence in the car performance; whereas trust intentions refer to intention to participate in trust-related behaviours with a specific brand. Trust beliefs therefore indicate the perception that a certain brand is trustworthy.

According to McKnight \& Chervany (2002), trust combines ability, benevolence, integrity and predictability. Ability denotes the perceived competence level of a brand, benevolence refers to the trustor's perceptions of the trustee's efforts, integrity represents righteous behaviour and predictability denotes the trustor's beliefs that the trustee will adhere to the promised transaction. In terms of Skoda, those elements can be perceived as meeting the latest car safety regulations and guidelines, or believing that cars will live up to their initial specifications and recommendations. Brand trust has not only a technical nature, seen in terms of its ability and willingness to keep promises and satisfy consumers' needs, but also good intentions regarding consumers' interests and welfare (Delgado et al, 2003). Thus, a 
trustworthy brand is one that consistently fulfils its promise to consumers through the way the product is developed, produced, sold, marketed and serviced.

Xie et al (2015) introduced brand trust created via identity expressiveness, i.e. identity based trust. Explicitly, identity based trust involves the trustworthiness that is created from the intrinsic consistency of shared values, goals or interests. In this respect, people exhibit tendencies to form psychological connections with brands that have shared values with themselves.

In order to examine the difference in trust perceptions across Poland and the UK, the following hypothesis pair is proposed:

H40: There is no significant difference in Skoda's trust perceptions between Poland and the UK. $H_{a}$ : There is a significant difference in Skoda's trust perceptions between Poland and the UK.

\section{Perceived Value}

As noted by Payne \& Holt (2001), two concepts form the foundations of value, and those are benefits and sacrifices. Sacrifices extend beyond just price, including non-financial factors such as time, effort or energy as well. The concept of perceived value describes the trade-off between what the consumer sacrifices in obtaining a product/service, and the benefits that the consumer gets from the product/service in return (Belal et al, 2013). Consumers do not purchase products per se, they do so in order to obtain utility. Therefore, perceived value is the difference between the utility provided by the product's attributes and the disutility due to the price and costs associated with the acquisition (Caruana et al, 2000). Furthermore, Zeithaml (1988) claimed that some consumers perceive value as a low price, whilst others see value in terms of a balance between quality and price.

Lee \& Overby (2004) identified two types of shopping values: utilitarian value and experiential value. Utilitarian value represents an overall assessment of functional benefits, such as price savings, service excellence or time savings. Experiential value, on the other hand, represents sensory benefits e.g. the aesthetic appeal or the entertainment provided. For Skoda, utilitarian value can be perceived by end of season price cuts or by offering low cost financing plans. Experiential value would be the appearance of the cars, by virtue of their visual attractiveness in colour, shape, etc.

The perceived value has been related to other concepts such as satisfaction and quality. These relationships were confirmed by Petrick (2002), who argued that perceived value was a notable determinant of satisfaction. Roig et al (2006) stated that consumers' perceived value actually originates from the integration between functional, emotional and social value. Functional value denotes attraction of the quality and expected performance of the product/service; emotional value refers to the feelings conjured up by the product/service and, finally, social value represents to the social prestige gained by ownership and explicit usage of the product/service.

Various studies (e.g. Choi \& Kim, 2013; Tam, 2004; inter alia) have confirmed that perceived value is a precursor of customer satisfaction, as well as having a positive effect on purchase intentions and brand preference.

In order to examine the difference in value perceptions across Poland and the UK, the following hypothesis pair is proposed:

H5: There is no significant difference in value perceptions of Skoda's brand between Poland and the UK.

H5: There is a significant difference in value perceptions of Skoda's brand between Poland and the UK.

\section{Purchase Intentions}

The interest exhibited by marketing scholars in purchase intentions emanates from its relation to buying behaviour. Studies have proven a positive correlation between purchase intentions and purchase behaviours (Morowitz \& Schmittlein, 1992; Morowitz et al, 1996). Purchase intention, as discussed by Dodds et at (2001), refers to the likelihood that a consumer will buy a certain product or service. Intentions differ from attitudes. Attitudes are summary evaluations, whereas intentions reflect a person's motivation through a conscious plan to make an effort to carry out a particular behaviour (Eagly \& Chaiken, 1993).

The theory of reasoned action, as discussed by Fishbein \& Ajzen (1980), posits that the intention of behaviour is determined by attitude toward the behaviour that relates to a person's positive or negative feelings about performing the target behaviour. Chu \& $\mathrm{Lu}(2007)$ found that the perceived effectiveness of a product has a significant influence on the consumer's purchase intention. Similarly, Lin \& Tsai (2006) 
found that consumers might decide to purchase a product/service when they think the product is effective. Additionally, consumers purchasing high-involvement products (such as cars) tend to seek related information and pay attention to the opinion of people around them before embarking on such decision making (Charters \& Pettigrew, 2006).

Traditionally, researchers have looked for factors that affect consumers' car purchases, with the main focus of assessing car manufacturers' market shares. The forecasts are usually based upon econometrics models that use choice data (Wheelan, 2007; Dargay, 2002). Those models identified a number of characteristics, such as size of the household, the status of occupants (i.e. occupation, education, health), as well as other characteristics such as type and tenure of accommodation (Clark, 2009). However, critics of those models have argued the importance of psychological factors related to car purchase decisions, such as concerns about the environment (Khan, 2007). Moreover, Jansson et al (2010) found that values, beliefs and norms had an impact on the purchase of alternative-fuel cars. As such, there is an argument to be made that psychological factors ought to be analysed alongside socio-demographic factors in order to improve our understanding of car purchase intentions.

In order to examine the difference in purchase intentions across Poland and the UK, the following hypothesis pair is proposed:

H6 $6_{0}$ : There is no significant difference in Skoda purchase intentions between Poland and the UK. $H 6_{a}$ : There is a significant difference in Skoda purchase intentions between Poland and the UK.

\section{Advertising}

Advertising may be considered as any form of promotional activity aimed at highlighting an idea, product, service, etc that requires monetary expense (Kotler \& Armstrong, 2011). It is of little surprise that advertising is one of the most apparent marketing activities.

Advertising may serve to affect brand equity in various ways. The customer judges the quality of the products from their internal and external symbols. The perceptions created or modified through advertising represents an external means to influence the perceived quality of the product/service (Kirmani \& Rao, 2000). Moreover, advertising investment can play a beneficial role in creating brand recognition and increased levels of brand awareness (Keller, 2013). Performed effectively, this can lead to an enhanced brand image. In general, consumers consider brands with heightened levels of advertising to be better, and of higher quality (Bravo et al, 2007).

Previous research has found that consumers' perception of advertising is vital in affecting brand equity (Keller \& Lehmann, 2006; Bravo et al, 2007). The effectiveness of advertising is evaluated by assessing the concept, the style, the medium and the frequency and reach of the campaign (Kotler, 2000). As such, advertising needs an appropriate plan and execution. Brands can attract attention by creating original, creative, fun and innovative marketing communications (Keller, 2013).

In order to examine the difference in advertising effect between Poland and the UK, the following hypothesis pair is proposed:

H7: There is no significant difference in perceptions of Skoda's advertising between Poland and the UK.

$\mathrm{H}_{a}$ : There is a significant difference in perceptions of Skoda's advertising between Poland and the UK.

\section{Country of Origin}

Country image is the overall perception consumers possess of products/services from a certain country, based on their previous perceptions of the country's production and marketing strengths and weaknesses (Roth \& Romeo, 1992).

Balestrini \& Gamble (2006) found that country of origin and brand image affect perceptions regarding quality of products/services, yet consumers from different countries have dissimilar perceptions. The image of the country might have an effect either enhancing or deteriorating consumers' beliefs or attitudes toward its brands. Consumers might integrate their positive or negative image about the country with the image of the brand and, for that reason, brand image and country of origin are correlated (Guercini \& Ranfagni, 2013).

Previous studies have indicated that general perceptions about a particular country tend to influence the evaluation of products associated with that country, irrespective of the level of consumer knowledge and experience of the products themselves (Laroche et al, 2005). Correspondingly, Hui \& Zhou 
(2003) discovered that the brand image of a known brand produced in a country renowned for that product category is likely to be seen in much more favourable terms than a known brand that originates from an unknown country. And, likewise, Srikatanyoo \& Gnoth (2002) found that consumers tend to develop certain stereotypical beliefs about products from certain countries and thus country of origin can affect evaluations of those brands.

But what happens when a brand is mistakenly perceived to have originated in a different country? The reaction is dependent on 1) the degree to which country $Y$ has a more positive/negative image than country $X$ according to consumers and 2) the degree to which a brand is stronger than the country it is associated with. Brand origin misclassifications can be either positive or negative (Pharr, 2005; Verlegh \& Steenkamp, 1999).

In order to examine the difference in country of origin effect between Poland and the UK, the following hypothesis pair is proposed:

H8: There is no significant difference in Skoda's country of origin perceptions between Poland and the UK. H8: There is a significant difference in Skoda's country of origin perceptions between Poland and the UK.

\section{Methodology}

This study made use of a survey approach to collect primary data. This allowed the researchers to collect large sample of respondents from Poland and the UK, which was then quantitatively scrutinised to understand the brand characteristics of Skoda (Bryman \& Bell, 2015; Saunders et al, 2007).Two groups of respondents aged 18 or over were recruited, one in Poland, the other in the UK. The researchers made use a snowball sampling to recruit respondents, who all fitted the profile of potential Skoda customers. Snowball sampling is a technique whereby existing participant recruit future participants from among their acquaintances or business contacts (Lewis-Beck et al, 2004).

The survey instrument, a questionnaire, consisted of eight sections of closed questions/statements that examined the various characteristics of the Skoda brand. Each question/statement used a Likert scale, whereby respondents were asked to choose a response from a 5 point scale ranging between 'strongly agree' and 'strongly disagree'.

The researchers conducted two pilot online questionnaires, one in Poland and one in the UK. The feedback received was positive and the respondents understood the questions and were happy with the time needed for completion. Therefore, only minor amendments were made prior to launching the main component of the survey.

The final questionnaire was created online via www.esurveycreator.co.uk. The data was collected throughout August 2016. The link for the questionnaire was made available on various social networks, such as Facebook and Twitter, as well as via emails. In total, $122(n=122)$ questionnaires were returned and $113(n=113)$ of them were fully completed and thus available for analysis. $58(n=58)$ contributors participated in the United Kingdom, and $55(n=55)$ in Poland.

The data was entered SPSS for descriptive and inferential analysis. However, before analysis was commenced, the researchers ran the Kolmogorov-Smirnov test to establish the data distribution. This test compares the score in the sample to a normally distributed set of scores with the same mean and standard deviation (Landers, 2013). It was found that the data from Purchase Intentions was normally distributed, whilst the other seven brand characteristics yielded non-normal distribution. Subsequently, the researchers executed the Independent Samples $\mathrm{T}$ Test for the normally distributed Purchase Intentions data, and non-parametric Mann-Whitney tests for the non-normally distributed brand image, price, perceived quality, trust, perceived value, advertising and country of origin constructs (Field, 2014).

\section{Discussion of Findings \\ Brand Image}

The study found that, overall, brand image of Skoda in both Poland and the UK was positive. However, Poland scored higher in each of the eight measured areas, as well as in total. Polish respondents were considerably more familiar with Skoda, and this score was the highest in the whole study $(\mathrm{M}=4.65$; $\mathrm{SD}=0.52$ ). The familiarity can be linked to the fact that Skoda is a Czech brand. Poland and the Czech Republic are neighbouring countries and have long-established closed relationship. Moreover, $98 \%$ of the sample from Poland was able to name at least model of Skoda cars and $89 \%$ could name at least two 
models. That result was much lower among UK respondents $-64 \%$ could name at least one model and only 50\% could name at least two models. These numbers support the familiarity results noted above. Additionally, the high familiarity with Skoda in Poland could be linked to the fact that $82 \%$ of the Polish sample correctly named the Czech Republic as the country of origin of Skoda. That result was much lower in the UK, and did not even reach $50 \%$. Almost a quarter of UK respondents (22.4\%) actually thought that Skoda was Polish.

Polish and UK respondents both believed Skoda to be reliable and attractive. However, yet again, Poland scored higher in those areas. Those findings corroborate observations by Kim \& Kim (2005) that positive brand image leads to a stronger brand with higher sales potential. Notably, this relationship is particularly evident in Poland where Skoda is the best-selling car. Moreover, Aghekyan-Simonian et al (2012) stated that the more favourable the brand image, the more positive the attitude towards the branded product and its attributes. This is evident in this instance, as Poland perceives Skoda's brand image to be highly favourable, with corresponding sales figures. Ataman \& Ulengin (2003) concluded that that positive brand image has a positive effect on sales. This conclusion is well mirrored in the current study.

It is worth mentioning that neither Poland nor the UK thought that Skoda was the leading brand in the car market. This result was to be expected in the UK, where other brands outsell Skoda. However, this outcome is at odds with sales performance in Poland.

The non-parametric Mann-Whitney test revealed a significant difference in Skoda's brand image between Poland and the UK. Here, the Brand image of Skoda in Poland $(\mathrm{M}=66.08)$ and in the United Kingdom $(M=44.92)$ was significantly different, $U=930.50, z=-3.49, p=<.001$. Therefore, the null hypothesis is rejected and the study accepts the alternative hypothesis.

\section{Price}

The study revealed virtually the same perceptions of price of Skoda amongst Polish and UK respondents. Both groups agreed that the price of Skoda was reasonable, affordable and appropriate. Bojanic (1996) stated that companies offer reasonable prices in order to maintain an advantage within very competitive markets. It would appear that Skoda is compliant with this in both the Polish and UK markets.

One particular question measured whether or not Skoda was "inexpensive". Although Poland and the UK thought of Skoda as inexpensive, the UK achieved a better result here. The UK has one of the most prosperous economies in the world and its inhabitants enjoy higher levels of disposable income than consumers in Poland. The effect of the economy may explain why respondents in the UK thought Skoda's prices were more affordable in this regard.

The non-parametric Mann-Whitney test revealed that there was no significant difference in Skoda's price perceptions between Poland and the UK. Here, Skoda's price perceptions in Poland $(\mathrm{M}=$ 56.33) and in the United Kingdom $(\mathrm{M}=56.68)$ did not differ significantly, $\mathrm{U}=1522.00, \mathrm{z}=-.11, \mathrm{p}=.914$. Therefore, the study fails to reject the null hypothesis and cannot accept the alternative hypothesis.

\section{Perceived Quality}

The findings revealed that both Polish and UK respondents viewed the quality of Skoda favourably. Both groups recorded very similar perceived quality scores. In the car industry, perceived quality may refer to the quality of appearance, material or detail. Therefore, the study measured how consumers compared the quality of Skoda with the Ford and Volkswagen brands, its major competitors. Somewhat surprisingly, both Polish and UK respondents agreed that Skoda was of better quality than Ford and Volkswagen. Those results are contradictory to what sales figures for 2015 reveal, namely that within the UK, the most popular car brand was Ford.

A similar disparity is observed in Poland. The sales figures for 2015 showed that Skoda was the most popular brand in Poland; however Polish respondents did not agree with the statement that Skoda offers the best quality. Whereas UK respondents thought that Skoda did offer the best quality, even though the sales figures showed otherwise. These results support findings of Parasuraman et al (2006), as well as of Cronin \& Taylor (2002), who also reported mismatches between perceived brand quality and consumer behaviour. 
The non-parametric Mann-Whitney test revealed that there was no significant difference in Skoda's perceived quality between Poland and the UK. Here, Skoda's perceived quality in Poland $(\mathrm{M}=$ 54.92) and in the United Kingdom $(\mathrm{M}=57.06)$ did not differ significantly, $\mathrm{U}=1480.50, \mathrm{z}=-.35, \mathrm{p}=.723$. Therefore, the study fails to reject the null hypothesis and cannot accept the alternative hypothesis.

\section{Trust}

The study found that overall both Poland and the UK had trust in Skoda. Poland, however, scored higher in each of the four questions. McKnight \& Chervany (2002) stated that trust combines ability and predictability. Respondents in Poland and in the UK agreed that cars sold by Skoda are indeed dependable. Furthermore, both groups believed that Skoda is honest about their cars' abilities and descriptions. This may be understood as the brand conforming to stringent safety regulations and living up to its claims. This affords Skoda a solid base for future development. This trust, evidentially, is reflected in increasing sales, particularly in Poland.

Furthermore, the notion of identity trust, as reported by Xie et al (2015), is corroborated in this study. Identity trust is based on consistency of shared values or interest. Both Polish and UK respondents scored favourable results in the question measuring confidence based on Skoda's values. The fact that consumers form psychological connections with brands that have shared values with them is a pleasing sign for Skoda.

The non-parametric Mann-Whitney test revealed that there was no significant difference in Skoda's trust perceptions between Poland and the UK. Here, Skoda's trust in Poland $(M=61.53)$ and in the United Kingdom $(M=51.65)$ did not differ significantly, $U=1291.00, z=-1.63, p=.104$. Therefore, the study fails to reject the null hypothesis and cannot accept the alternative hypothesis.

\section{Perceived Value}

Polish and UK respondents agreed that Skoda offers good value. Zeithaml (1988) claimed that some consumers perceive value as a low price, whilst others see value as the compromise between quality and price. This assertion has been confirmed in the study. Polish and UK respondents claimed that Skoda was worth purchasing and offered good value for money. As noted previously, Skoda's price and quality was well received across the board. Therefore, the perceived value is correspondingly deemed to be high. However, it should be acknowledged that perceived value is not exclusively considered in monetary terms, but may also be seen in terms of non-financial facets such as effort or time (Payne \& Holt, 2001).

The non-parametric Mann-Whitney test revealed that there was no significant difference in Skoda's perceived value between Poland and the UK. Here, Skoda's perceived value in Poland $(\mathrm{M}=60.55)$ and in the United Kingdom $(M=52.59)$ did not differ significantly, $U=1344.50, z=-1.33, p=.184$. Therefore, the study fails to reject the null hypothesis and cannot accept the alternative hypothesis.

\section{Purchase Intentions}

The research found that, overall; Polish and UK respondents did not exhibit particularly favourable purchase intentions of Skoda, with Polish consumers more likely to want to own a Skoda car than their British counterparts. Previous studies have found a positive correlation between purchase intentions and purchase behaviours (Morowitz \& Schmittlein, 1992; Morowitz et al, 1996). These assertions are borne out in this study, bearing in mind the sales figures previously discussed in section 4.3.

Interestingly, both Polish and UK respondents agreed that Skoda would not be their first choice car. These findings are particularly interesting in terms of Polish consumers, bearing in mind that Skoda was the best-selling car in 2015.This discrepancy may be a result of the small sample size, or perhaps extraneous factors not encapsulated within the research instrument. However, one possible factor may be found in the literature. Khan (2007) stressed the importance of psychological factors related to car purchase decisions. Here, respondents from both Poland and the UK agreed that Skoda did not represent their personalities.

The Independent Samples T Test revealed that there was no significant difference in Skoda's purchase intentions between Poland and the UK. On average, participants in Poland recorded better purchase intentions of Skoda $(\mathrm{M}=2.86, \mathrm{SE}=0.12)$ than those in the UK $(\mathrm{M}=2.64, \mathrm{SE}=0.09)$. This difference, -0.21 , was not significant $t(99.51)=-1.39, p=.168$. Therefore, the study fails to reject the null hypothesis and cannot accept the alternative hypothesis. 


\section{Advertising}

The findings revealed that Polish and UK respondents positively viewed Skoda's advertising. Both sets of respondents agreed that Skoda has pleasing media visibility. This could be one of the insights that explain Skoda's increasing sales.

Advertising affects brand equity in several ways. Kirmani \& Rao (2000) and Keller (2013) argued that advertising investment pays dividends in terms of increased brand awareness, and that advertising can accrue positive benefits by means of elevating perceived quality. Previous research by Keller \& Lehmann (2006) and Bravo et al (2007) found that consumers' perception of advertising is vital in determining brand equity. The respondents from the UK and from Poland stated that they liked Skoda's adverts. They further agreed that Skoda's adverts were suitably informative, although not humorous. There may be elements (e.g. humour) that the brand is neglecting in their marketing communications, thus preventing these ads from fully resonating with consumers.

The non-parametric Mann-Whitney test revealed that there was no significant difference in perceptions of Skoda's advertising between Poland and the UK. Here, Skoda's advertising perceptions in Poland $(M=60.79)$ and in the United Kingdom $(M=49.52)$ did not differ significantly, $U=1177.00, z=-$ $1.88, p=.060$. Therefore, the study fails to reject the null hypothesis and cannot accept the alternative hypothesis.

\section{Country of Origin}

Overall, both Polish and UK respondents had positive opinions of the Czech Republic. Poland, in fact, possessed a very favourable disposition in this regard. Both set of respondents agreed that the Czech Republic was a well-developed country, with a reputation for design. Those opinions would presumably be of benefit to Skoda, as Ballestrini \& Gamble (2006) and Guercini \& Ranfagni (2013) found that the image of the country is positively correlated to the product brand, giving rise to either a halo effect or, alternatively, deteriorating consumers' beliefs and attitudes toward the brand in question. As respondents generally held a positive view of the Czech Republic, this played into the hands of Skoda's brand. Furthermore, Polish respondents very strongly associated Skoda with the Czech Republic. UK respondents did share a similar view, although to a lesser extent

Another insight in this area revealed that neither Polish nor UK respondents associated car manufacturing with the Czech Republic. Hui \& Zhou (2003) discovered that the brand image of a known brand produced in a country renowned for that product category is likely to be seen in more favourable terms than a known brand that originates from an unknown country. In this regard, Skoda does extremely well as its overall brand image is undoubtedly positive, yet consumers do not associate car manufacturing with the Czech Republic. Here, it would appear that Skoda punches above its weight, especially amongst Polish consumers.

The Skoda - Czech Republic association was also emphasised in another insight. Polish respondents stated that the country of origin of Skoda was important as Poland and the Czech Republic were neighbours and had shared tradition and history. These factors, patently, were not applicable to British consumers, due to the geographic distance separating the UK and Czech Republic.

The non-parametric Mann-Whitney test revealed that there was no significant difference in Skoda's country of origin effect between Poland and the UK. Here, country of origin perceptions in Poland $(M=60.40)$ and in the United Kingdom $(M=51.68)$ did not differ significantly, $U=1298.00, z=-$ $1.43, p=.152$. Therefore, the study fails to reject the null hypothesis and cannot accept the alternative hypothesis.

\section{Conclusions and Limitations of the Study}

The objective of this study was to examine various brand characteristics of Skoda among consumers in the United Kingdom and in Poland. The study also investigated whether sales are mirrored in the brand image of Skoda in the UK and in Poland. Brand image and its related aspects such as price, quality, trust, value, purchase intentions, advertising and the concept of the country of origin were assessed.

The study produced some fascinating results. The concept of brand image is complex and multifaceted. The study found that, in general, the core brand image of Skoda in both Poland and in the UK, 
was largely positive. However, Polish respondents perceived the image to be considerably better, with Polish consumers much better acquainted with the Skoda brand.

The study revealed similar perceptions of Skoda's pricing amongst consumers from both sets of respondents. Both groups agreed that the price of Skoda was reasonable, affordable and appropriate. The findings of the study also revealed that both Polish and UK consumers favourably perceive the quality of Skoda. Both groups scored almost identically in this respect. Although Skoda was the 2015 best-selling car in Poland, respondents did not agree with the statement that Skoda offers the best quality. The study also found that, overall, both Poland and the UK had trust in the Skoda brand. Yet, again, Poland scored higher in the series of trust questions, although this did not record a significant difference. Polish and UK respondents agreed that Skoda offered good value. Respondents in Poland reflected more desire to own a Skoda than UK respondents, underscoring higher sales of Skoda in Poland. However, both sets of respondents agreed that Skoda would not be their first choice of motorcar.

Moreover, the research unveiled that both Polish and UK consumers perceived Skoda's advertising in a positive light, liking Skoda's adverts. However, there was scope for optimising campaigns and perhaps striking a different tone of message e.g. embracing humorous content to engage the audience in a light-hearted manner. Overall, both Polish and UK respondents had positive opinions of the Czech Republic. However, it would appear that Polish consumers feel a closer affinity with the Czech Republic, due to these countries being continental neighbours.

In synopsis, the following conclusions were reached:

- Brand image: A significant difference between Poland and the UK was recorded, with the former cohort being significantly more positive about the Skoda brand

- $\quad$ Price, perceived quality, trust, perceived value, purchase intentions, advertising, country of origin: There was no significant difference recorded between Poland and the UK

There are three limitations to this research worth mentioning. First, the study only utilised a mono-method quantitative strategy. Further context may be required in due course, as the Likert type questions did not permit respondents to elaborate their answers in qualitative terms. Second, the sample acquired was fairly small and may not comprehensively represent perceptions throughout Poland and the UK. Third, there was a disproportion in age and gender amongst participants from the UK and Poland. Therefore, closely aligning the samples in terms of these demographics may produce more accurate results.

Looking forward, there is scope to pursue further cross-country analysis e.g. Czech Republic and the UK, or Poland and Ireland. A more comprehensive demographic analysis, using a larger sample, may yield valuable insight between different cohort's e.g. different age groups and income brackets. This would address the second limitation noted above. Finally, a follow-on study may be useful to determine why brand image alone (and not the other factors) differed between Poland and the UK. Here, qualitative research may shed further light on this.

\section{References}

Aaker, D. (1991) Managing brand equity: Capitalizing on the value of brand name. New York: The Free Press.

Aghekyan-Simonian, M., Forsythe, S., Kwon, W.S. \& Chattaraman, V. (2012) The role of product brand image and online store image on perceived risks and online purchase intentions for apparel. Journal of Retailing and Consumer Services, 19, (3), p.325-331.

American Marketing Association [online]. Available:

https://www.ama.org/resources/Pages/Dictionary.aspx?dLetter=B [Sept 19 th 2016].

Anwar, A., Gulzar, A., Sohail, F.B. \& Akram, S.N. (2011) Impact of brand image, trust, and effect on consumer brand extension attitude: the mediating role of brand loyalty. International Journal of Economics and Management Sciences, 1, (5), p.73-79.

Ataman, B. \& Ulengin, B., (2003) A note on the effect of brand image on sales. Journal of Product \& Brand Management, 12, (4), p.237-250.

Bajpai, P. (2015) The World's Top 10 Economies [online]. Available:

http://www.investopedia.com/articles/investing/022415/worlds-top-10-economies.asp [Sept 19th 2016]. 
Balestrini, P. \& Gamble, P. (2006) Country-of-origin effects on Chinese wine consumers. British Food Journal, 108, (5), p.396-412.

Belal, H. M., Shirahada, K. \& Kosaka, M. (2013) Value co-creation with customer through recursive approach based on Japanese Omotenashi service. International Journal of Business Administration, 4, (1), p.28-38.

Blumberg, B., Cooper, D.R. \& Schindler, P.S. (2005) Business Research Methods. Maidenhead: McGrawHill.

Bravo, R., Fraj, E. \& Martinez, E. (2007) Family as a source of consumer-based brand equity. The Journal of Product and Brand Management, 16, (3), p.188-199.

Broniatowski, M. (2015) What does Poland Need to Keep Its Economy On the Move? [online]. Available: http:/ / www.forbes.com/sites/forbesinternational/2015/10/07/what-does-poland-need-to-keepits-economy-on-the-move/\#72f3d91e2c81 [Sept 16 ${ }^{\text {th }}$ 2016].

Bryman, A. \& Bell, E. (2015) Business Research Methods [4 ${ }^{\text {th }}$ Edition]. Oxford: Oxford University Press.

Caruana, A., Money, A.H., \& Berthon, P.R. (2000) Service quality and satisfaction: The moderating role of value. European Journal of Marketing, 34, (11/12), p.1338-1352.

Charters, S. \& Pettigrew, S. (2006) Product involvement and the evaluation of wine quality. Qualitative Market Research, 9, (2), p.181-193.

Choi, E. J. \& Kim, S.-H. (2013) The Study of the Impact of Perceived Quality and Value of Social Enterprises on Customer Satisfaction and Re-Purchase Intention. International Journal of Smart Home, 7, (1), p.239-252.

Chu, C.W. \& Lu, H.P. (2007) Factors influencing online music purchase intention in Taiwan. Internet Research, 17, (2), p.139-155.

Clark, S.D. (2009) The determinants of car ownership in England and Wales from anonymous 2001 census data. Transportation Research Part C, 17, p.526-540.

Collis, J. \& Hullis, R. (2003) Business Research: A practical guide for undergraduate and postgraduate students [2 $2^{\text {nd }}$ Edition]. Houndmills: Palgrave Macmillan.

Cronin, J. \& Taylor, S. (2002) Measuring service quality: a re-examination and extension. Journal of Marketing, 56, p.55-58.

Dargay, J.M. (2002) Determinants of car ownership in rural and urban areas: a pseudo-panel analysis. Transportation Research Part E, 38, p.351-366.

Delgado, E., Munuera, J.L. \& Yague, M.J. (2003) Development and validation of a brand trust scale. International Journal of Market Research, 45, (1), p.35-54.

Dodds, W.B., Monroe, K.B. \& Grewal, D. (2001) Effects of price, brand, and store information on buyers product evaluations. Journal of Marketing Research, 28, (3), p.307-319.

Eagly, A.H. \& Chaiken, S. (1993) The Psychology of Attitude. New York: Harcourt Brace College Publishers.

English, A. (2011) Skoda celebrates 20 years of success under VW [online]. Available:

http://www.telegraph.co.uk/motoring/car-manufacturers/skoda/8458395/Skoda-celebrates-20-yearsof-success-under-VW.html [Sept 19th 2016].

Field, A. (2014) Discovering Statistics using IBM SPSS Statistics [4 $4^{\text {th }}$ Edition]. London: SAGE Publications.

Fishbein, M. \& Ajzen, I. (1980) Understanding attitudes and predicting social behaviour. Englewood Cliffs, NJ: Prentice Hall.

Ganesan, S. (1994) Determinants of long-term orientation in buyer seller relationships. Journal of Marketing, 58, (2), p.1-19.

Goldberg, M.E., Gorn, G. \& Pollay, R.W. (1990) Advances in Consumer Research. Provo, UT: Association for Consumer Research.

Guercini, S. \& Ranfagni, S. (2013) Integrating country-of-origin image and brand image in corporate rebranding: the case of China. Marketing Intelligence \& Planning, 31, (5), p.508-521.

Hui, K.M. \& Zhou, L. (2003) Country of manufacture effects for known brands. European Journal of Marketing, 37, (1/2), p.133-153.

Jacoby, J. \& Olson, J. (1995) Perceived Quality. Lexington, MA: Lexington Books. 
Jacoby, J., Syzbillo, G. \& Busato-Sehach, J. (1997) Information Acquisition Behaviour in Brand Choice Situations. Journal of Marketing Research, 11, p.63-69.

Jansson, J., Marell, A. \& Nordlund, A. (2010) Green consumer behaviour: determinants of curtailment and eco-innovation adoption. Journal of Consumer Marketing, 27, p.358-370.

Johnson, B. \& Christensen, L. (2012) Educational Research: Quantitative, Qualitative and Mixed Approaches [4 $4^{\text {th }}$ Edition]. London: Sage Publications.

Juster, N. P., Maxfield, J., Dew, P.M. \& Taylor, S. (2001) Predicting Product Aesthetic Quality Using Virtual Environments. Journal of Computing and Information Science in Engineering, 1, (2), p.105112.

Kahn, M.E. (2007) Do greens drive Hummers or hybrids? Environmental ideology as a determinant of consumer choice. Journal of Environmental Economics and Management, 54, p.129-145.

Keller, K.L. (1993) Conceptualizing, measuring, and managing customer-based brand equity. Journal of Marketing, 57, (1), p.1-22.

Keller, K.L. (2013) Strategic Brand Management: Building, Measuring, and Managing Brand Equity [4 $4^{\text {th }}$ Edition]. London: Pearson.

Keller, K.L., \& Lehmann, D.R. (2006) Brands and branding: Research findings and future priorities. Marketing Science, 25, (6), p.740-759.

Kim, H.B. \& Kim, W.G. (2005) The relationship between brand equity and firms' performance in luxury hotels and chain restaurants. Tourism Management, 26, p.549-560.

Kim, H.W., Xu, Y. \& Gupta, S. (2012) Which is more important in Internet shopping, perceived price or trust? Electronic Commerce Research and Applications, 11, (3), p.241-252.

Kim, S.J., Choi, Y.K., Kim, K.H. \& Liu, H. (2015) Country of origin and brand image influences on perceptions of online game quality. Journal of Consumer Behaviour, 14, (6), p.389-398.

Kirmani, A., \& Rao, A.R. (2000) No pain, no gain: A critical review of the literature on signalling unobservable product quality. Journal of Marketing, 64, p.66-79.

Knapmann, C. (2013) Skoda: from laughing stock to top dog [online]. Available:

http:// www.telegraph.co.uk/motoring/car-manufacturers/skoda/10018605/Skoda-from-laughingstock-to-top-dog.html [Sept 19th, 2016].

Kotler, P. \& Armstrong, G. (2011) Marketing: An Introduction [11 th Edition]. New Jersey: Prentice Hall.

Kotler, P. (2000) Marketing management. Englewood Cliffs, NJ: Prentice Hall.

Koubaa, Y. (2006) COO: who uses it, when and how it is used. Taiwan: Global Business and Technologies Association.

Kozlowski, P. (2016) Najczesciej kupowane samochody w 2015 r. w Polsce [online]. Available:

http:/ / moto.pl/MotoPL/56,88389,19436611,najczesciej-kupowane-samochody-w-2015-r-w-polsce.html [Sept 19th, 2016].

Landers, R. N. (2013) A step by step introduction to statistics for business. London: SAGE Publications.

Laroche, M., Papadopoulos, N., Heslop, L.A. \& Mourali, M. (2005) The influence of country image structure on consumer evaluations of foreign products. International Marketing Review, 22, (1), p.96-115.

Law, G.S. \& Lamb, C.W. (2000) The measurement and dimensionality of brand associations. Journal of Product \& Brand Management, 9, (6), p.350-368.

Lee, E.J. \& Overby, J.W. (2004) Creating value for online shoppers: implications for satisfaction and loyalty. Journal of Consumer Satisfaction, Dissatisfaction, and Complaining Behaviour, 17, p.54-67.

Left-lane [online]. Available: http://left-lane.com/european-car-sales-data/skoda/ [Sept 19th, 2016].

Leone, R.P., Rao, V.R., McAlister, I. \& Srivastava, R. (2006) Linking brand equity to customer equity. Journal of Service Research, 9, (2), p.125-138.

Lichtenstein, D.R., Ridgway, N.M. \& Netemeyer, R.G. (1993) Price perceptions and consumer shopping behavior: a field study. Journal of Marketing Research, 30, (2), p.234-245.

Lin, C.H. \& Tsai, C.C. (2006) Comparisons and advertising: The route from comparisons to effective advertising. Journal of Business and Psychology, 21, (1), p.23-44. 
Llusar, J.C.B., Zornoza, C.C. \& Tena, A.B.E. (2001) Measuring the relationship between firm perceived quality and customer satisfaction and its influence on purchase intentions. Total Quality Management, 12, p.719- 734.

McKnight, D.H. \& Chervany, N.L. (2002) What trust means in E-commerce customer relationships: an interdisciplinary conceptual typology. International Journal of Electronic Commerce, 6, (2), p.35-59.

McKnight, D.H., Choudhury, V. \& Kacmar, C. (2002) Developing and validating trust measures for ecommerce: an integrative typology. Information Systems Research, 13, (3), p.334-359.

McNamee, M.J. (2007) Research Ethics in Exercise, Health and Sport Sciences. London: Routledge.

Meenaghan, T. (1995) The role of advertising in brand image development. Journal of Product and Brand Management, 4, (4), p.23-34.

Morwitz, V.G. \& Schmittlein, D. (1992) Using segmentation to improve sales forecasts based on purchase intent: which intenders actually buy? Journal of Marketing Research, 29, p.391-405.

Morwitz, V.G., Steckel, J. \& Gupta, A. (1996) When Do Purchase Intentions Predict Sales? New York: Stern School of Business.

Oakshott, L. (2006) Essential Quantitative Methods: for business, management and finance [3rd Edition]. Houndmills: Palgrave Macmillan.

Parasuraman, A., Zeithaml, V. \& Berry, L. (2006) The behavioural consequences of service quality. Journal of Marketing, 60, p.31-46.

Patton, M.Q. (2015) Qualitative Research and Evaluation Methods [4 $4^{\text {th }}$ Edition]. London: Sage Publications.

Petrick, J.F. (2002) Development of a multi-dimensional scale for measuring the perceived value of a service. Journal of Leisure Research, 34 (2), p.119-134.

Pharr, J.M. (2005) Synthesizing Country-of-Origin Research from the Last Decade: Is the Concept Still Salient in the Era of Global Brands? Journal of Marketing Theory and Practice, 13, (4), p.34-45.

Piatkowski, M. (2013) Poland's New Golden Age: Shifting from Europe's periphery to Its Center. Policy Research Working Paper, 6639, p.1-34.

Piatkowski, M. (2015) How Poland Became Europe's Growth Champion: Insights from the Successful Post-Socialist Transition [online]. Available: http://www.brookings.edu/blogs/futuredevelopment/posts/2015/02/11-poland-post-socialist-transition-piatkowski [Sept 19th, 2016].

Rao, A.R. \& Monroe, K.B. (1999) The effect of price, brand name, and store name on buyers' perceptions of product quality: an integrative review. Journal of Marketing Research, 26, p.351-357.

Roig, J.C.F., Garcia, J.S., Tena, M.A.M. \& Monzonis, J.L. (2006) Customer perceived value in banking services. International Journal of Bank Marketing, 24, (5), p.266-283.

Roselius, T. (1991) Consumer Ranking of Risk Reduction Methods. Journal of Marketing, 35, p.56-61.

Roth, M.S. \& Romeo, J.B. (1992) Matching product category and country image perceptions: a framework for managing country of origin effects. Journal of International Business studies, 23, (3), p.477-497.

Rust, R.T. \& Oliver, R.L. (2004) Service Quality: New Directions in Theory and Practice. Thousand Oaks, CA: Sage Publications.

Ryu, K., Han, H. \& Kim, T.H. (2008) The relationships among overall quick-causal restaurant image, perceived value, customer satisfaction, and behavioural intentions. International Journal of Hospitality Management, 27, (3), p.459-469.

Saarinen, M. (2016) Best-selling cars 2015: record year for the UK car sales [online]. Available: http:/ / www.autoexpress.co.uk/ best-cars/90327/ best-selling-cars-2015-record-year-for-uk-carsales [Sept 19th, 2016].

Saunders, M., Lewis, P. \& Thornhill, A. (2007) Research Methods for Business Students [4 ${ }^{\text {th }}$ Edition]. Harlow: FT Prentice Hall.

Singh, J. \& Sirdeshmukh, D. (2000) Agency and trust mechanisms in consumer satisfaction and loyalty judgments. Journal of the Academy of Marketing Science, 28, (1), p.150-167.

Skoda PL [online]. Available: http://www.skoda-auto.pl/ [Sept 19th, 2016].

Skoda UK [online]. Available:

https://media.skoda-auto.com/en/_layouts/Skoda.PRPortal/pressrelease.aspx?ID=963 [Sept 19 ${ }^{\text {th }}, 2016$ ]. 
Söderberg, R., Wickman, C. \& Lindkvist, L. (2006) Improving Decision Making by Simulating and Visualizing Geometrical Variation in Non-Rigid Assemblies. CIRP Annals-Manufacturing Technology, 57, (1), p. 175-178.

Srikatanyoo, N. \& Gnoth, J. (2002) Country image and international tertiary education. Journal of Brand Management, 10, (2), p.139-148.

Tam, J. L. M. (2004). Customer satisfaction, service quality and perceived value: An integrative model. Journal of Marketing Management, 20, (7-8), p.897-917.

Verlegh, P.W.J. \& Steenkamp, J.B. (1999) A Review and Meta-Analysis of Country-of-Origin Research. Journal of Economic Psychology, 20, (5), p.521-46.

Wang, J.H. \& Holden, J. (2000) Craftsmanship Evaluation in Automotive Products. International Journal of Industrial Engineering, 7, (4), p.286-290.

Whelan, G. (2007) Modelling car ownership in Great Britain. Transportation Research Part A, 41, p.205219.

Which [online]. Available: http://www.which.co.uk/cars/skoda/ [Sept 19th, 2016].

Wilson, R. \& Crouch, E.A. (1987) Risk assessment and comparisons: an introduction. Science, 236, (4799), p.267-270.

Xie, Y., Batra, R. \& Peng, S. (2015) An extended model of preference formation between global and local brands: The roles of identity expressiveness, trust, and affect. Journal of International Marketing, 23, (1), p.50-71.

Yoon, S., Oh, S., Song, S., Kim, K. K. \& Kim, Y. (2014) Higher quality or lower price? How value-increasing promotions affect retailer reputation via perceived value. Journal of Business Research, 67, (10), p.2088-2096.

Zeithaml, V.A. (1988) Consumer perceptions of price, quality, and value: a means-end model and synthesis of evidence. Journal of Marketing, 52, (3), p.2-22. 